\title{
School Spaces for Coexistence and Democracy
}

\author{
Montes Ponce Wendy Margarita, Sumano Sánchez Esteban, López Altamirano Otniel Josafat \\ Universidad Autónoma Benito Juárez de Oaxaca (UABJO), Oaxaca, México
}

\begin{abstract}
The architecture for education as a contemporary problem requires new strategies for solution; the work presented aims to expose projects that reveal the possibility of a school architecture based on the values of coexistence and the promotion of democracy. Approaches that architect in the Chilean Republic, as in Spain, have shown if it is possible and emergent that architecture for education offers new models that promote the development of all the actors implicit in education.
\end{abstract}

Keywords: school, classroom, coexistence, democracy, architecture

\section{Introduction}

The present work emanates from an investigation that has been developing for a year and a half. The theme is related to the understanding of architecture as a learning tool; the results that have been obtained define new research questions: Can architecture be understood as a means for learning; that is, can it overcome its condition as a shell that crowd students and teachers, to become involved as an object of greater connection with educators and learners? And what factors have architects not considered in relation to the educational architecture that continues to be built with the classroom prototype of 50 years ago? The preliminary conclusions have shown that it is possible that the classrooms have a different category in the universe of pedagogy.

\section{Foundational Objective of Democratic Classrooms}

\section{Study Development}

Key factor to modify the educational architecture is coexistence; the Model of the Ministry of Education of the Government of Chile, entrusts the learning focused on “... coexistence [as] one of the experiences that most profoundly mark the lives of students ... the Politics National School Coexistence declares a series of approaches to guide the school/lyceum, from the Classrooms of Good Being ...” (Ministry of Education, 2017, p. 19). Approaches recognized from the field of ethics, rights, participation, gender, and inclusion. So according to the purposes of the Ministry, the participation of architects is essential, while it is recognized that:

Eje participación, inclusión y formación democrática: reconoce y potencia el ejercicio de derechos en cada actor de la comunidad educativa, validándolos como protagonistas en la construcción de espacios educativos inclusivos, de cuidado y bienestar, donde se favorezca la creatividad y el diálogo entre todos/as, promoviendo una cultura escolar de respeto a la

\footnotetext{
Montes Ponce Wendy Margarita, Doctor of architecture, Professor of the Faculty of Architecture, Universidad Autónoma Benito Juárez de Oaxaca (UABJO), Oaxaca, México.

Sumano Sánchez Esteban, Doctor of architecture, Professor of the Faculty of Architecture, Universidad Autónoma Benito Juárez de Oaxaca (UABJO), Oaxaca, México.

López Altamirano Otniel Josafat, Architecture Master, Professor of the Faculty of Architecture, Universidad Autónoma Benito Juárez de Oaxaca (UABJO), Oaxaca, México.
} 
identidad y a la diversidad sin distinción de etnia, género, religión o nacionalidad. (Ministerio de Educación, 2017. p. 50)

Within this first framework, a first confirmation has been located about the need for a more appropriate educational architecture; since from the interests of this Chilean institution, the challenge is not limited to the learning of coexistence in schools as a matter of social limits; it also implies the space in which learning takes place.

Within this same interest, initiatives have been located to create Schools for Democracy: “...escuela activa que superara la tradicional pasividad del alumno fomentando su aprendizaje a través de una escuela que fuera jardín y taller...” (Muñoz, 2012, p. 11). The search for an educational architecture that implies spaces for the development of democracy has generated projects that aim to crystallize the objective. From the political reforms in Spain, the educational rules concluded that, democracy was a matter of values that should be included in educational centers; therefore, the school represents the source of these values. For the above, and according to the conclusions disseminated in an article in the magazine Politics and Society, of the Complutense University:

... Si la escuela no es capaz de generar espacios para la deliberación, la contrastación de pareceres, el conocimiento del otro, el reconocimiento de muy diferentes destrezas y competencias más allá de las tradicionalmente académicas, es poco menos que imposible que formemos una ciudadanía democrática... (Feito, 2010, p. 55)

Democracy then, fostered in the quality of coexistence, within the educational centers, proposes to resolve when considering concrete conditions, such as: freedom for the development of ideas, belief in individual and collective capacity, promotion of critical reflection, the procuring of dignity and rights, the learning of the values of democracy, and the institutional linkage (Feito, 2010, p. 56). Certainly, in the face of these conditions, the search for a solution to the goal of democratic classrooms has been resolved in the student's education and its relationship with the rest of the students. However, the antecedent to the case goes back the proposal to schools built during the third decade of the last century, when the School and Culture Board of Bilbao, Spain, requested seven primary schools, intended for populous neighborhoods. So, after a contest, of the 18 finalist projects, the selected architecture was inclusive when considering open and public spaces that would facilitate active learning (Muñoz, 2012, p. 11). It was a property that was governed by a courtyard linked by a park of free access, which was established as the distribution axis of five buildings.

Los arquitectos [Madariaga y Zarránz] hubieran preferido proyectar pabellones de menor altura o de un solo piso, como los que eran habituales en algunos centros escolares de Frankfurt, que permitían unas condiciones higiénico-pedagógicas más adecuadas; o desarrollar, al menos, los diferentes servicios en edificios autónomos que permitiesen una mayor superficie de espacio libre. Pero tenían que elaborar un programa amplio y de reducido coste en poco espacio y en un terreno en desnivel, lo que les obligaba a integrar los diferentes servicios en bloques conjuntos... (Muñoz, 2012, p. 12)

According to the source, the school would turn out to be a prototype of an educational architecture, distant from traditional learning spaces. It was a flexible construction that met the basic and particular needs, from quadrangular, rectangular cells and the combination of open or covered spaces; inclusive spaces, designed for students with or without special needs. The conclusions that the educators would issue about the facilities coincided in that the school was more active and participatory thanks to the characteristics of the classrooms, being open spaces, of variable size and regulated lighting and mobile furniture. So, the impact that the school would have on the education of Bilbao, would be recognized by the Ministry of Public Instruction when 
granting four million pesetas for the construction of other pedagogical spaces of the same architectural nature.

Deserves singular recognition that educational centers built under the principles of democratic classrooms, are resolved according to who learns; notable difference to the traditional school spaces that are built considering the needs of the one who teaches:

...lo fundamental es que la gente salga de la escuela con la capacidad para preguntarse sobre lo que le rodea, para analizar con criterios propios la realidad, para ser alguien dispuesto a seguir aprendiendo a lo largo de toda su vida... Esto significa que el acercamiento al conocimiento escolar... es radicalmente diferente del que tiene lugar en la escuela tradicional... (Feito, 2009, p. 18)

And it is equally important to note that these spaces for education originally belonged to the public sector, at the basic level; however, in view of the resulting educational quality, nowadays the private sector has promoted its construction for the basic and upper secondary levels; mainly at the end of the Franco period. However, the model of democratic centers, based on curricular globalization, has undergone changes in spaces such as libraries, by integrating furniture and medium-technology equipment; altering in an important way of the understanding of school coexistence. On the other hand, the latest studies that have been developed in relation to the level of learning within democratic spaces, show one of the damages in the students; I have been the separation by levels of educational performance, because this separation does not promote coexistence democratic, but on the contrary accentuates it, sectorizing school facilities; reproducing the school model by exclusion, from which it is argued that intelligence is a determining factor in school classification.

One of the strategies that have been put in place for the reduction of attitudes by exclusion is centered on the development of assemblies among the students: “...Las asambleas son un instrumento privilegiado del aprendizaje significativo... Más que de asamblea deberíamos hablar de ágora, puesto que de lo que se trata es de propiciar el escenario en el que fluya la palabra ordenada del alumnado...” (Feito, 2009, p. 22). Of course, the stage, the agora, is materialized through an architectural site whose main feature is the opening of spatial boundaries; although, not necessarily with the formality of a semicircular forum of Greek typology, yes a covered place, flexible that propitiates the quality of the exchange of thoughts. Space when observing the architectural plan of the architects Madariaga and Zarránz, is determined by a covered forum, adjoining the areas: áulica, recreation, and dining rooms. Considering then that the educational centers for democracy are beginning their renovation process, in accordance with the contemporary pedagogical demands, the sources give an account of the integration of computer rooms, which seek to promote the learning of a second language, besides generating the approach with cultural expressions between local or foreign ethnic populations.

The classroom, in the concept of these spaces for democracy, is identified as a sample object: The doors, the walls, the hygienic zones, the boards, are destined to spaces of permanent communication:

Las aulas están sumamente vivas que la posición física del observador resulta complicada... no está claro cuál sea la parte frontal o trasera del aula. Los niños se mueven con gran libertad. En definitiva se trata de aulas que incitan a la aventura del trabajo intellectual. (Feito, 2009, p. 28)

Added to the above, the architectural proposals of democratic spaces for education show that the environment acquires a priority importance. The conclusion that has been reached in this regard is focused on the wide range of learning opportunities offered by the environment, mainly because of the connection established between knowledge and its application in reality; scopes within the traditional educational centers do not seem to be regular. 


\section{Conclusions}

Now that you have exposed some architectural examples, you can ensure that the research questions posed at the beginning of this document, if they have affirmative answers. The works of Spanish colleague's show that educational centers, as architectural objects, if they exceed their condition of shell, wrap for the overcrowding of school communities. It is equally clear that professionals in construction must deal with the understanding of the profile of the learner, developing spaces that involve human values that are decisive in stimulating the learning process; that consideration is given to the promotion of coexistence and democracy among the subjects involved in educational centers, and of other values such as the ability to transform spatial qualities, as a heritage for those who follow them in learning. Therefore, the results that were exposed, not only represent the confirmation of an architecture that is emerging reproduce; it is an invitation to understand a noble discipline, as is pedagogy, to enhance the efforts of its actors and interpreters. So, the research on the subject requires, evaluates other sources, and then develops disciplinary meetings, which add the approaches of the pedagogue with the architect, and undertake architectural proposals that represent constructive models more assertive for the development of the educational universe.

\section{References}

Feito, R. (2009). Democratic schools Spain. Rase Magazine of the Association of Sociology of Education, 2(1), 18-56.

Feito, R. (2010). Schools and democracy. Spain. Political and Society Magazine, 47(2), 47-61. Complutense University of Madrid.

Ministry of Education. (2017). Intersectoral management model. Classrooms of well-being. Santiago, Chile: Chile's Government. Muñoz, F. (2012). The school for democracy. School architecture and II Republic in Bilbao, Spain. Academic Bulletin. Magazine of Investigation and Contemporary Architecture, 10(19), 107-129. 